\title{
Application of Copper Fungicide and Row Covers to Control Phytophthora Seedling Blight Disease on Cocoa
}

\author{
Febrilia Nur 'Aini ${ }^{1 *}$, Teguh Iman Santoso ${ }^{1)}$ and Sudarsianto ${ }^{1)}$ \\ ${ }^{1)}$ Indonesian Coffee and Cocoa Research Institute, J1. PB Sudirman No. 90, Jember 68118, Indonesia \\ ${ }^{*}$ Corresponding Author: febrilia.ifeb@yahoo.com \\ Received: 15 June 2016 / accepted: 26 July 2016
}

\begin{abstract}
Phytophthora seedling blight disease is one of the important diseases in cocoa. The disease is caused by the fungus of Phytophthora palmivora belongs to class Oomycetes. The aim of this research was to determine the effectiveness of the use of row covers and copper oxide fungicide applications to control seedling blight Phytophthora. Covering treatment was to place cocoa seedlings inside bamboo frame covered by transparent plastic in order to avoid from rainfall effect. The research was conducted in the Kaliwining Experimental Station at Indonesian Coffee and Cocoa Research Institute (ICCRI). Experiments were carried out four treatments and repeated 6 times. Each treatment consists of 100 seedlings planted in polybags and placed in the nursery area with a protective paranet. The treatment consisted of (1) row covers, (2) spraying of copper oxide $0.2 \%$, (3) a combination of row covers and copper oxide $0.2 \%$ and (4) control (no covers and spray). Observations made 7 days after treatment with an interval of 7 days for 10 weeks. The results showed that row covers able to prolong the incubation period of the disease for 14 days, while the application of row covers + copper oxide $0.2 \%$ was able to save cocoa seedlings by $96.2 \%$.
\end{abstract}

Keywords: cocoa seedlings blight disease, Phytophthora palmivora, row covers, copper oxide

\section{INTRODUCTION}

Phytophthora blight seedling disease is one of the most dangerous cocoa diseases. The disease infects cocoa seedlings and caused death pathogen grows easily in wet area with humidity almost $100 \%$ (McMahon $\&$ Purwantara, 2004). The intensity of the disease will be higher in the humid plantation with poor drainage.

The seedling blight disease caused by fungus Phytophthora palmivora from Oomycetes class which is soil-borne so that the inoculum is always present in the soil. P. palmivora has a dormant capability especially in an unfavorable climate by forming chlamydospores. As a consequence, controlling P. palmivora blight seedling disease is a considerable challenge for most cocoa farmers around the world.

Besides seedling blight disease, $P$. palmivora also causes pod rot and stem cancer disease in cocoa. Based on the field experience, in wet climates cocoa seedlings death due to Phytophthora seedling blight disease can reach more than $50 \%$. Therefore, appropriate control strategy to reduce the level of seedling death caused by the disease is necessary.

The disease control strategy was focused on reducing primary inoculum source through sanitation (Guest, 2007). Controlling seedling blight diseases can be done by quarantine, using resistant clone and biological control agents (Sri-Sukamto, 2003; Pratama 
et al., 2013) as well as the application of chemical fungicides. Copper is one of active ingridient of contact fungicide was used to prevent Phytophthora seedling blight disease (Guest, 2007). $\mathrm{Cu}++$ was able to damage and kill some prominent enzymes in pathogenic fungi.

The purpose of this study was to determine the effectiveness of the combination of the use of row cover and copper fungicide applications to control Phytophthora seedling blight disease. Research on the disease was still rarely to be conducted although, in fact, losses caused by this disease were very large. Therefore, the results of this study were expected to provide important information can be used to control Phytophthora seedling blight disease.

Seedling row cover is one of the critical success factors of cocoa seedling growth because it can accelerate the growth and regeneration of cells (Yuliasmara, 2015). The role of row cover in cacao seedling growth is to keep the air temperature and humidity remain stable so that the metabolism of plants is maintained. Additionally, row cover is also able to control the diseases caused by soil-borne pathogens such as Phytophthora, Fusarium, Pythium and Rhizoctonia.

\section{MATERIALS AND METHODS}

Phytophthora seedling blight diseasecontrol study was conducted in Kaliwining Experimental Station, Indonesian Coffee and Cocoa Research Institute at $45 \mathrm{~m}$ altitude and flat topography. The maximum temperature is $33^{\circ} \mathrm{C}$ minimum temperature is $21,6^{\circ} \mathrm{C}$. Solar radiation is $70 \%$ relative humidity of $87 \%$ and evaporation $3.75 \mathrm{~mm}$ per day. It is classified with rainfall type D based on Schmidt and Ferguson in which the average rainfall is $1,957 \mathrm{~mm} /$ year and the wet months 6.5 months/year .
P. palmivora detection in the experiment was performed as Purwantara (2008). The purpose of $P$. palmivora fungal inoculum detection was to determine the presence of fungal inoculum in the soil. It was conducted by feeding healthy cocoa pods which were placed on $0 \mathrm{~cm}$ from the ground. The numbers of infected pod were counted and the percentage of infection was measured. The infected pod was then isolated at the Laboratory of Plant Protection, Indonesian Coffee and Cocoa Research Institute, by cutting the cocoa pods on the boundary between the healthy and rot part. Disinfection was conducted using sodium hypochlorite $1.5 \%$ for two minutes, followed by $70 \%$ alcohol solution for two minutes before it was washed in sterile water and dried on sterile tissue paper. Cocoa shell pieces were placed in a petridish containing potato dextrose medium, and then incubated for seven days. Next, the fungal growth and sporulation of P. palmivora were observed.

The material used was cocoa seeds from the open pollination of TSH 858 clone. The seeds were soaked in water for 24 hours using the method taken by Pancaningtyas et al. (2014) before it was planted in the media consists of soil and sand mixture with $1: 1$ ratio. The media was put in a $0.5 \mathrm{~kg}$ sized polybag and placed on the ground,

The experiment consisted of four treatments with six replications. Each treatment consists of 100 half-sib cocoa seeds clone TSH 858. The treatment consisted of (1) transparent plastics row cover, (2) spraying $0.2 \%$ copper-oxide every two weeks to the entire plant (volume $10 \mathrm{ml} /$ polybag), (3) a combination of plastic row cover and $0.2 \%$ copper oxide which was sprayed every two weeks, and (4) control. Cocoa seeds were planted in polybags and placed in a protective embankment using paranet with $30 \%$ diffuse light. Row cover was performed by inserting cacao seedlings 
into a bamboo frame covered by transparent plastic at the size of $220 \mathrm{~cm} \times 100 \mathrm{~cm} \mathrm{x}$ $70 \mathrm{~cm}$. The cocoa seedlings in the row cover should be watered every day. The row cover could only be opened from morning until early afternoon when it was not raining.

Observations on the Phytophthora seedling blight disease was performed after seven days treatment with a seven-day interval for 10 weeks. Observation was conducted by opening the lid first and then observing all variables such as symptoms of the disease, incubation period, intensity of the disease, rate of infection, effectiveness of treatment against the disease and seedling growth. Phytophthora seedling blight disease symptoms were indicated by wither and blackish brown leaves. Then, the infection spreaded to all parts of the plant caused it to wither and defoliate and eventually resulted in the death of the seedlings (Figure 1).
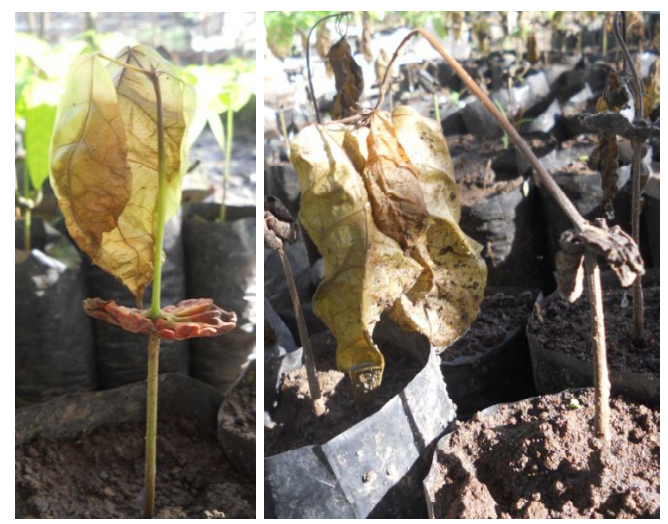

Figure 1. Symptom of Phytophthora seedlings blight

The incubation period was calculated since the inoculation until the early symptom appeared in a unit of day after inoculation (hsi). The calculation of the intensity of the disease was measured by using the formula, $I P=\frac{n}{N} \times 100 \%$

Where:

$n=$ number of seedlings and blight seedling symptoms. $N=$ total number of seeds tested.
Infection rate was calculated based on Van der Plank (1963) formula:

$\mathrm{r}=2.3 / \mathrm{t}(\log 1 /(1-\mathrm{Xt})-\log 1 /(1-\mathrm{Xo}))$,

Where :

$\mathrm{r}$ = rate of infection (unit/ day).

$\mathrm{Xo}=$ proportion of early disease.

$\mathrm{Xt}=$ proportion of disease at time $\mathrm{t}$

$\mathrm{t}=$ time of observation.

The effectiveness of treatment was calculated by the following formula:

$T E=\frac{I P k-I P p}{I P k} \times 100 \%$

Where :

$T E=$ rate of effectiveness $(\%)$.

$I P k=$ Intensity of blight seedling disease control /no treatment. $I P p=$ Intensity of blight seedling disease in treatment.

Observation on the growth of cocoa seedlings was conducted by measuring plant height, stem diameter and number of leaves. Data were analyzed using Statistical Analysis System (SAS) version 9.1. If there was a significance difference, a further mean separation test based on Duncan's Multiple Range Test (DMRT) on the 95\% level of significance would be performed.

\section{RESULTS AND DISCUSSION}

\section{Inoculum Detection}

Inoculum detection showed the location of cocoa breeding contained P. palmivora fungal inoculum as the source of Phytophthora disease. Detection of fungi $P$. palmivora aimed to find out the source of inoculum disease when the experiment carried out. There were $50 \%$ cocoa pods on the ground at the edge of the embankment which showed the symptoms of pod rot after the third day and it was indicated that all the pods rot on the fifth day (Table 1). Meanwhile, in the middle of the beds, the cocoa pods infected by disease on the third day were $60 \%$ and on the fifth day, $100 \%$ of the cocoa pods had been infected. Based on the results, it was known that the source of $P$. palmivora fungal inoculum was 
located in the edge and the middle of the nursery.

$P$. palmivora fungi detection was followed by isolation of disease-causing fungi. The isolation of $P$. palmivora fungi showed spherical colonies with uneven and white edges (Figure 2). Ovoid shape Sporangia with a wide section near the bottom has a prominent papilla (Semangun, 2000) and short pedicle (Sri-Sukamto, 1985). P. palmivora pedicle size is $<5 \mu \mathrm{m}$, and varies in length, for around 40-60 $\mu \mathrm{m}$, width for around $20-40 \mu \mathrm{m}$ at the length ratio of 1.4 to 2.0 $\mu \mathrm{m}$ (Erwin \& Ribeiro, 1996).

P. palmivora has four types of spores that can cause an infection namely sporangia, zoospores, oospore and chlamydospores (Vanegtern et al., 2015). Sporangia produced in the fruits, leaves, stems and roots which are infected can germinate directly on the surface of the plant or in the soil and it is able to produce zoospores. Zoospores can swim in the water, soil and plant surface to detect cracks into the plant as a way to penetrate inside the plant (Bowers et al., 2001). Chlamydospore is produced asexually and can survive for months on the ground when there is no host. Spores will germinate when there is a host plant on the supporting weather (Guest, 2007) .

\section{Disease symptoms}

Phytophthora seedling blight infection was started from the stem toward the top. The leaves wither and became blackish brown. Then, infection spread to the entire stem, causing wilting, defoliation and eventually seedling death. Based on the visual observation on the symptoms, it is known that the control treatment (D) showed a high percentage of deaths due to Phytophthora seedling blight disease (Figure 3 ). It is caused by less protection against fungal $P$. palmivora compared to other treatments.

P. palmivora is dispersed through water splash (Sri-Sukamto, 1985). As a soil-borne pathogens, the water splash is one of the fungus infection carrier on cocoa seedlings. The water splashes which infect the plants can reach up to $75 \mathrm{~cm}$ height from ground level (Guest, 2007). Zoospores release and germination occurs in $15-30^{\circ} \mathrm{C}$ free water (Purwantara, 1990). Zoospores take at least 20-30 minutes at free water on plant surfaces prior to germinate and penetrate into the host tissue (Guest, 2007), whereas infection occurs

Table 1. Detection of fungal inoculum $P$. palmivora on cocoa nursery

\begin{tabular}{cllllll}
\hline \multirow{2}{*}{ Sample, pods } & \multirow{2}{*}{ Location } & \multicolumn{5}{c}{ Infected pod (\%) after (days) } \\
\cline { 3 - 7 } & & 1 & 2 & 3 & 4 & 5 \\
\hline \multirow{2}{*}{10} & Edge of nursery & 0 & 0 & 50 & 80 & 100 \\
10 & Middle of nursery & 0 & 0 & 60 & 80 & 100 \\
\hline
\end{tabular}

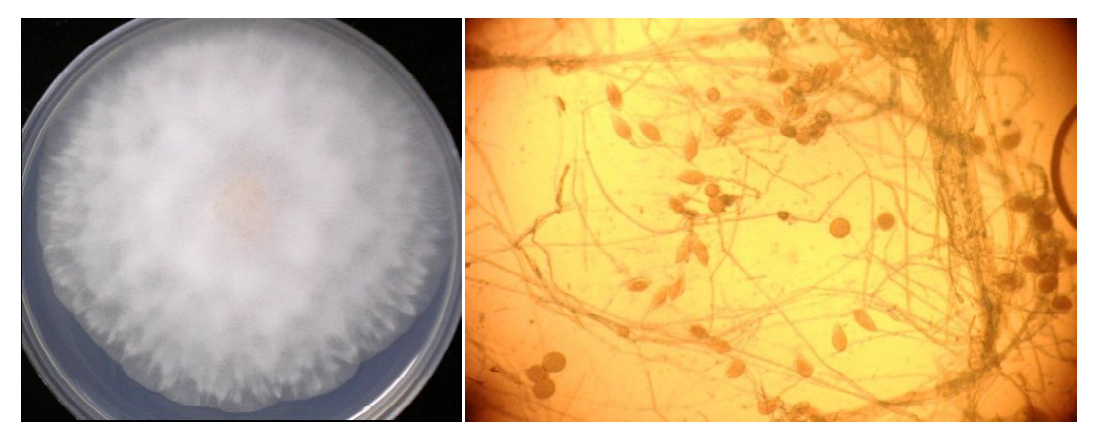

Figure 2. Fungal colonies of P. palmivora on PDA media (left). Sporangium of $P$. palmivora at $400 \mathrm{x}$ magnification (right). 


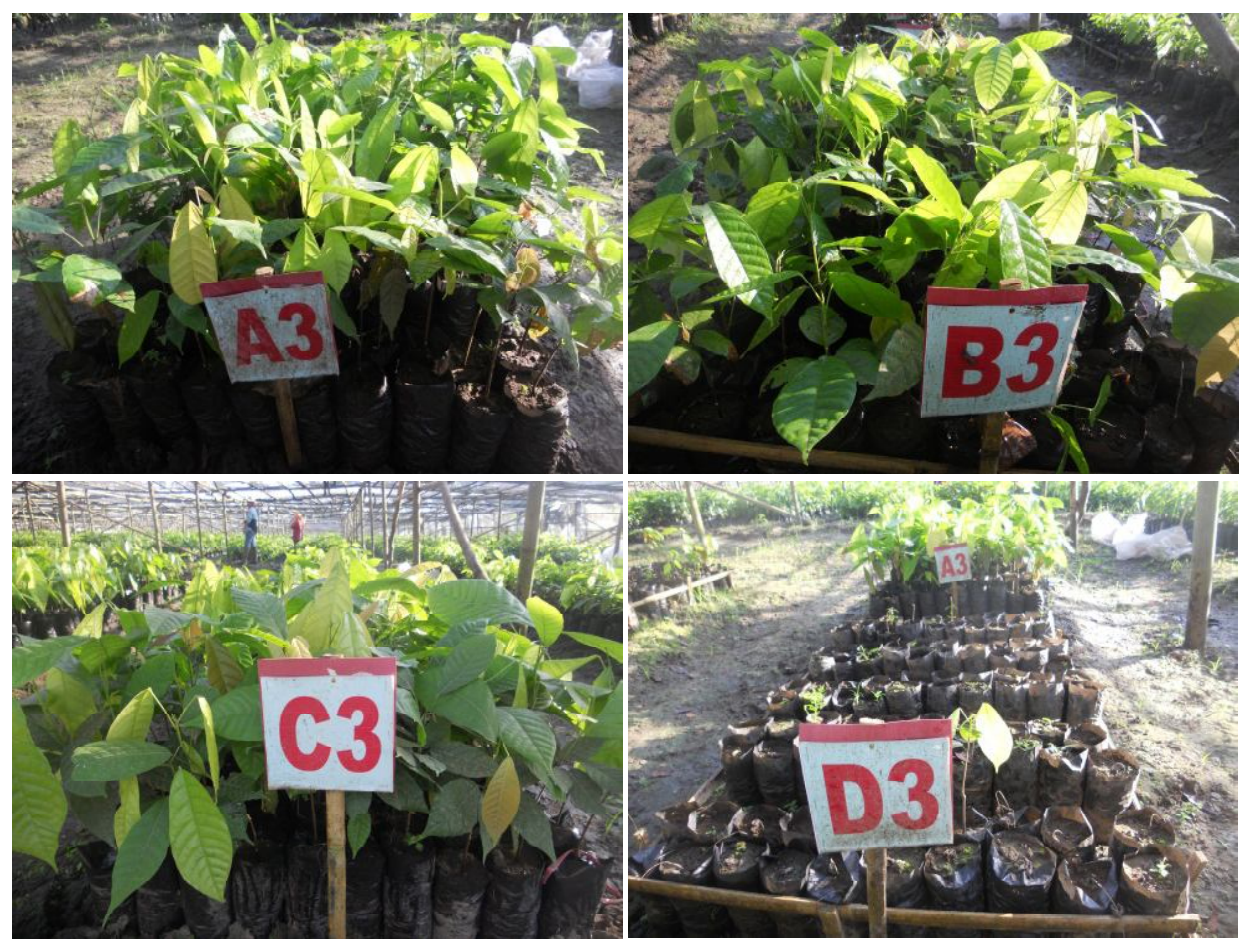

Figure 3. The symptom of Phytophthora seedling blight disease; (A) row covers, (B) spraying of copper oxide $0.2 \%,(\mathrm{C})$ a combination of row covers and copper oxide $0.2 \%$ and (D) control (no treatment).

at a temperature of $20-30^{\circ} \mathrm{C}$ (Purwantara, 1990). High surface plants' humidity and wetness have a considerable influence on the occurrence of infectious diseases (Purwantara, 1990), so that seedlings which are not protected by row cover and $0.2 \%$ copper oxide has higher potential to be infected by Phythophthora seedling blight disease, as shown in the control group (Figure 3 D).

\section{Severity}

Phytophthora seedling blight disease severity are presented in Table 2. In the first week, the control treatment showed that the severity of Phytophthora blight seedling disease was $7.1 \%$, while row cover treatment indicated $0.2 \%$ severity. Based on the experiment, it is known that infections of Phytophthora blight seedling disease can kill cocoa seedlings within seven days after infection. This is consistent with the experiments conducted by Pawirosoemardjo \& Purwantara (1992) on the cocoa pods of various clones which showed that the time required by the fruit to decay due to $P$. palmivora infections is seven days .

Based on Table 2, it is known that the intensity of Phytophthora seedlings blight in the control group grown exponentially since the first week until eighth week after the treatment. After the eighth week, there was not any increase on the intensity of the disease until the end of the observation. Based on the patterns of the development intensity of Phytophthora seedling blight, it is known that the susceptible phase of cocoa seedlings against the disease is up to eight weeks (two months). Therefore, the most appropriate time to control row cover, as preventive action, is before it is grown in a planting medium.

In the tenth observation, it was known that the lowest intensity of Phytophthora 
seedling blight disease was $3.8 \%$ in the combination of row cover and the $0.2 \%$ copper oxide, or able to save seedlings by $96.2 \%$ compared to control group. The low intensity of the disease was in line with the low rate of $P$. palmivora infection (Table 3 ). It showed that the combination of row cover and $0.2 \%$ copper oxide had a better ability to suppress the intensity and rate of infection of the disease on cocoa seedlings. The row cover is allegedly able to suppress the spread of fungal inoculum, while the fungicide copper oxide is able to suppress $P$. palmivora populations.

\section{Treatment Effectiveness}

From Table 3, it can be identified that the use of row cover on cocoa seedlings were able to prolong the incubation period of the disease up to 14 days after treatment. In addition, the use of row cover could effectively suppress infection by $78.2 \%$ with an infection rate of 0.0051 units/day. As $P$. palmivora is soil-borne fungi, the use of row cover on cocoa seedlings gave a significant impact on suppression of Phytophthora seedling blight disease because it could protect the seedlings from infection through water splash.

The use of $0.2 \%$ copper oxide indicated $65.5 \%$ level of effectiveness with an infection rate of 0.0175 units/day. Copper oxide is a contact fungicide which should be applied before the infection occurred. The rate of infection run faster at without row cover condition compared to with row cover or combination of row cover $+0.2 \%$ copper oxide condition.

The Lowest infection rate was indicated by combination of row cover $+0.2 \%$ copper oxide at 0.003 units per day by $84.7 \%$ level of effectiveness. Environmental factors such as temperature, humidity and rainfall rate were known to influence the activity of the pathogen and host susceptibility (Agrios, 2005).

\section{Seedling Growth}

Based on Table 4, it can be seen that the plant height at treatment with row cover and combination of row cover $+0.2 \%$ copper oxide was significantly differ from the treatment with $0.2 \%$ copper oxide and controls. In

Table 2. Disease severity of Phytophthora seedling blight on cocoa

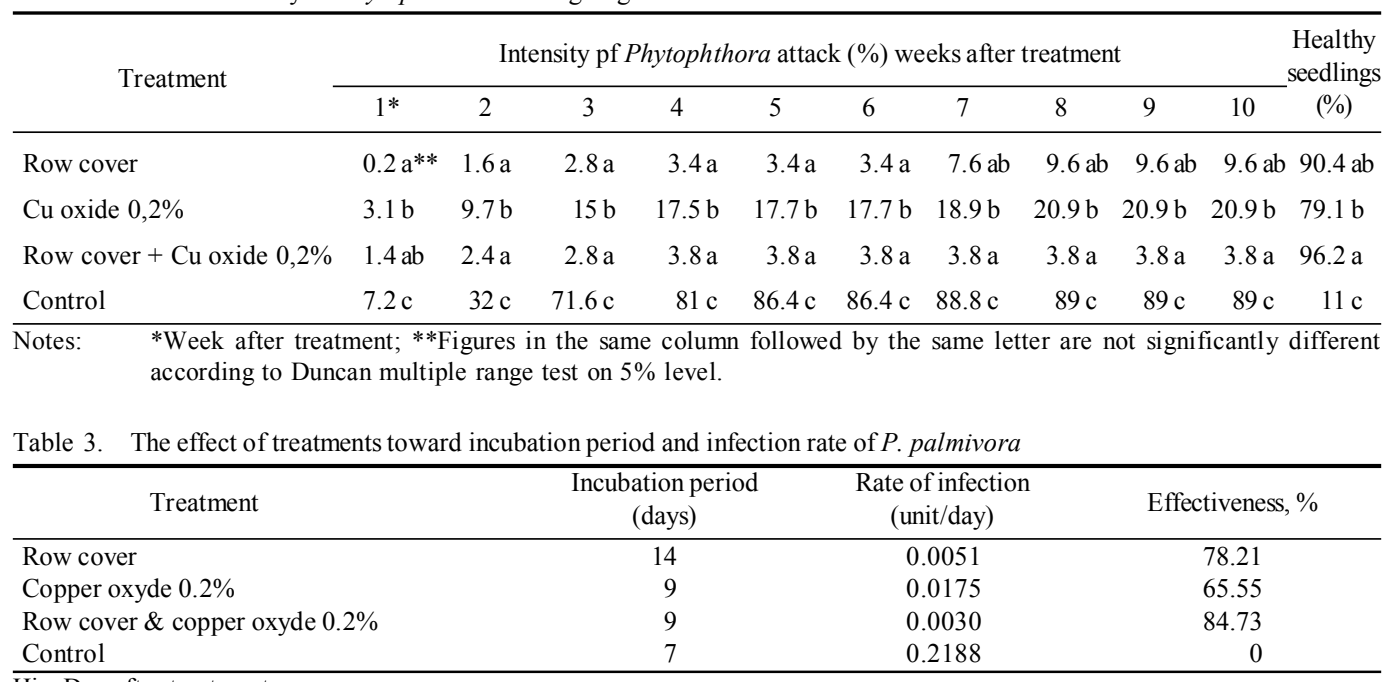

His: Day after treatments 
the third month, the seedlings treated with row cover $+0.2 \%$ copper oxide grew into $26.2 \mathrm{~cm}$ and $23.8 \mathrm{~cm}$ respectively; while the height of plant where the seedlings were treated with $0.2 \%$ copper oxide fungicide and control group reached $19.9 \mathrm{~cm}$ and $19.8 \mathrm{~cm}$. It showed that row cover had the most significant effect on the growth of plant height, while the application of $0.2 \%$ copper oxide fungicide had no effect on plant growth. Copper oxide is thought to be more involved in suppression of seedling blight disease infection but had no effect on plant growth.

According to Yuliasmara (2015), row cover is one of the critical success factors of cocoa seedling. Row cover can accelerate seedling growth and regeneration of cells primarily on seed obtained by cuttings and grafting. This is presumably due to the warm temperatures inside the row cover. In warm temperatures, the metabolism of plants is more active than at low temperatures and, as a result, the impact on plant growth and development is better.

Row cover is basically to manage the micro-climate, particularly temperature and humidity. The temperature inside the row cover will be high for up to $49^{\circ} \mathrm{C}$ during the day (Sudarsianto et al., 2009). High temperature has been reported as one of effective methods to kill Phytophthora in contaminated soil (Pscheidt, 2009). Zoospore release and germination occurs at $15-30^{\circ} \mathrm{C}$, whereas Phytophthora disease infection occurs at 20-30 ${ }^{\circ} \mathrm{C}$ (Purwantara, 1990).
Sudarsianto et al. (2009) have reported that the humidity inside the row cover can reach $100 \%$ even during the day. High humidity inside the row cover keep the plant cell turgidity so as not to become dehydrated. However, high humidity is also risky in attacking other fungi.

Based on the results of the discussion, it can put forward some technical implications of these results. Row cover on cocoa seedlings is an effective method for controlling Phytophthora seedling blight disease which spread through water splashes, so that the use of row cover can protect cocoa seedlings by blocking the water splash which bring the source of inoculum to the ground. The combination of row cover and $0.2 \%$ copper oxide is able to provide greater protection to cocoa seedlings compared with single treatment. It is revealed that the phase of cocoa seedlings is susceptible to Phytophthora since the seed is still in the nursery up to two months old. Consequently, disease control measures must be carried out preventively since the seed is planted on the bed-area to suppress the intensity of the disease.

\section{CONCLUSIONS}

Combination of row cover and $0.2 \%$ copper oxide sprayed has better ability of suppressing the infection of Phytophthora seedling blight disease on cocoa seedlings compared to single treatment row cover,

Table 4. Effect of treatments on diameter, height and number of leaves on cocoa seedling

\begin{tabular}{lrrrrrrrrr}
\hline \multirow{2}{*}{ Treatments } & \multicolumn{3}{c}{ Diameter, cm } & \multicolumn{3}{c}{ Height, cm } & \multicolumn{3}{c}{ No. of leaves } \\
\cline { 2 - 10 } & $1 *$ & 2 & 3 & 1 & 2 & 3 & 1 & 2 \\
\hline Row cover & $2.86 \mathrm{~b} * *$ & $3.19 \mathrm{a}$ & $4.07 \mathrm{a}$ & $15.38 \mathrm{a}$ & $20.74 \mathrm{a}$ & $26.15 \mathrm{a}$ & $3.31 \mathrm{a}$ & $5.69 \mathrm{a}$ & $8.73 \mathrm{a}$ \\
Copper oxyde $0.2 \%$ & $2.72 \mathrm{~b}$ & $3.03 \mathrm{a}$ & $4.08 \mathrm{a}$ & $11.56 \mathrm{~b}$ & $14.59 \mathrm{~b}$ & $19.9 \mathrm{~b}$ & $2.51 \mathrm{~b}$ & $5.17 \mathrm{a}$ & $7.74 \mathrm{a}$ \\
Row cover \& copper oxyde 0.2\% & $4.63 \mathrm{a}$ & $3.92 \mathrm{a}$ & $4.14 \mathrm{a}$ & $15.08 \mathrm{a}$ & $17.74 \mathrm{a}$ & $23.84 \mathrm{a}$ & $2.99 \mathrm{a}$ & $5.15 \mathrm{a}$ & $8.1 \mathrm{a}$ \\
Control & $2.85 \mathrm{~b}$ & $3.04 \mathrm{a}$ & $3.91 \mathrm{~b}$ & $10.99 \mathrm{~b}$ & $13.82 \mathrm{~b}$ & $19.8 \mathrm{~b}$ & $2.49 \mathrm{~b}$ & $4.04 \mathrm{~b}$ & $7.22 \mathrm{a}$ \\
\hline Notes: & * Month after treatment; ** Figures in the same column followed by the same letter are not significantly different
\end{tabular}


or $0.2 \%$ copper oxide spraying only. Besides to suppress Phytophthora seedling blight disease infection, row cover also can improve the performance growth of cocoa seedlings in the nursery.

\section{ACKNOWLEDGEMENT}

The author would like to thank Imam Ghozali, Surani and Herwanto and colleagues at Cocoa Breeding Section for their help so that this research can be completed.

\section{REFERENCES}

Agrios, G.N. (2005). Plant Pathology. Elsevier Academic Press. Heidelberg.

Bowers, J.H.; B.A. Bailey; P.K. Hebbar; S. Sanogo \& R.D. Lumsden (2001). The impact of plant diseases on world chocolate production. Online. Plant Health Progress. doi:10.1094/PHP-2001-070901-RV.

Erwin, D.C. \& O.K. Ribeiro (1996). Phytophthora Diseases Worldwide. St Paul Minnesota, APS Press, USA.

Guest, D. (2007). Black pod: Diverse pathogens with a global impact on cocoa yield. Phytopathology, 12, 1650-1653.

McMahon, P. \& A. Purwantara (2004). Phytophthora on cocoa (in) diversity and management of Phytophthora in Southeast Asia. ACIAR Monograph No. 114, 104-115.

Pancaningtyas, S; T.I. Santoso \& Sudarsianto (20!4). Studi perkecambahan benih kakao melalui metode perendaman. Pelita Perkebunan, 30, 190-197.

Pawirosoemardjo, S. \& A. Purwantara (1992). Laju infeksi dan intensitas serangan Phytophthora palmivora (Butl.) Butl. pada buah dan batang beberapa varietas kakao. Menara Perkebunan, $60,67-72$.

Pratama, S.W.; Sri-Sukamto; I.N. Asyiah \& Y.V. Ervina (2013). Penghambatan pertumbuhan jamur patogen kakao Phytophthora palmivora oleh Pseudomonas fluorescens dan Bacillus subtilis. Pelita Perkebunan, 29, 120-127.

Pscheidt, J.W. (2009). Plant Disease. p. 217-229. In: Chalker-Scott (Eds.). Sustainable Landscapes and Gardens: Good Science-Practical Application. Good Fruit Grower Publishing. Washington, USA.

Purwantara, A. (1990). Pengaruh beberapa unsur cuaca terhadap infeksi Phytophthora Palmivora pada buah kakao. Menara Perkebunan, 3, 78-83.

Purwantara, A. (2008). Infection of Phytophthora palmivora from soil in cocoa plantation. Pelita Perkebunan, 24, 205-218.

Semangun, H. (2000). Pengantar Ilmu Penyakit Tumbuhan. Gadjah Mada University Press. Yogyakarta.

Sri-Sukamto (2003). Pengendalian secara hayati penyakit busuk buah kakao dengan jamur antagonis Trichoderma harzianum. Seminar Ilmiah dan Kongres Nasional PFI XVI, Bandung, 6-8 Agustus 2003.

Sri-Sukamto (1985). Phytophthora palmivora Butler, salah satu jamur penyebab penyakit pada tanaman cokelat. Menara Perkebunan, 1, 7-11.

Sudarsianto.; T.I. Santoso \& S. Wardani (2009). Pembesaran Kakao Somatic Embryogenesis. Pusat Penelitian Kopi dan Kakao Indonesia.

Van der Plank, J.E. (1963). Plant Diseases: Epidemics and Control. Academic Press. New York, USA.

Vanegtern, B.; M. Rogers \& S. Nelson (2015). Black pod rot of cacao Caused by Phytophthora palmivora. Plant Disease, $108,1-5$.

Yuliasmara, F. (2015). Manajemen pembibitan tanaman kakao.p. 171-202. In: T. Wahyudi; Pujiyanto \& Misnawi (Eds.). Kakao: Sejarah, Botani, Proses Produksi, Pengolahan, dan Perdagangan. Gadjah Mada University Press. Yogyakarta.

$$
* * 0 * *
$$

